Pendas : Jurnal IImiah Pendidikan Dasar, ISSN Cetak : 2477-2143 ISSN Online : 2548-6950

Volume V Nomor 02, Desember 2020

\title{
PENINGKATAN BERPIKIR KRITIS SISWA SEKOLAH DASAR DENGAN MENERAPKAN MODEL CONTEXTUAL TEACHING AND LEARNING BERBANTUAN MEDIA LEMPAR KARET PENGETAHUAN
}

\author{
Dwi Hesti Lilis Setyawati ${ }^{1}$, Fina Fakhriyah², Khamdun ${ }^{3}$ \\ ${ }^{123}$ PGSD FKIP Universitas Muria Kudus \\ 1hestiliis1@gmail.com, 2fina.fakhriyah@umk.ac.id, 3Khamdun@umk.ac.id
}

\begin{abstract}
This research was conducted to describe the improvement of students' critical thinking skills by applying the Contextual Teaching and Learning learning model aided by the Media Rubber Throwing media. The research carried out included classroom action research with the research subjects of class IV students totaling 19 students. Data collection techniques in this study are tests and non-tests, data analysis used that the researcher used in this study is qualitative and quantitative data. The results showed that is increases the students' critical thinking skills. This is evidenced by the average percentage at the pre-cycle stage obtained a percentage of $52.8 \%$ with the criteria for guidance. In cycle 1 it increased to $70.39 \%$ with the sufficient criteria, and on the second cycle increases to $82.5 \%$ with a good criteria. Based of the results of this study, the researcher conclude that through the application of the Contextual Teaching and Learning model assisted by the Throwing Rubber Knowledge media can improve students' critical thinking skills on theme 6 of my ideals in grade IV SD 2 Tenggeles.
\end{abstract}

Keywords: C T L, Critical Thinking, Throw Rubber Knowledge

\section{ABSTRAK}

Penelitian ini dilakukan untuk mendeskripsikan peningkatan kemampuan berpikir kritis siswa dengan penerapan model pembelajaran Contextual Teaching And Learning berbantuan media Lempar Karet Pengetahuan. Penelitian yang dilakukan ini termasuk penelitian tindakan kelas dengan subyek penelitian siswa kelas IV berjumlah 19 siswa. Teknik pengumpulan data dalam penelitian ini adalah tes dan non tes, analisis data yang digunakan dalam penelitian ini adalah analisis data kualitatif dan kuantitatif. Hasil penelitian menunjukkan terjadinya peningkatan kemampuan berpikir kritis siswa. Hal ini dibuktikan dengan rata-rata presentase pada tahap pra siklus diperoleh presentase $52,8 \%$ dengan kriteria perlu bimbingan. Pada siklus 1 meningkat sebesar $70,39 \%$ dengan kriteria cukup. Kemudian pada siklus II meningkat menjadi $82,5 \%$ dengan kriteria baik. Berdasarkan hasil penelitian dapat disimpulkan bahwa melalui penerapan model pembelajaran Contextual Teaching And Learning berbantuan media Lempar Karet Pengetahuan dapat 
Pendas : Jurnal IImiah Pendidikan Dasar, ISSN Cetak : 2477-2143 ISSN Online : 2548-6950

Volume V Nomor 02, Desember 2020

meningkatkan kemampuan berpikir kritis siswa pada tema 6 cita-citaku kelas IV SD 2 Tenggeles.

Kata kunci: C T L, Berpikir Kritis, Lempar Karet Pengetahuan

\section{A. Pendahuluan}

Pembelajaran yang diterapkan dalam kurikulum 2013 adalah pembelajaran tematik yaitu memadukan beberapa muatan pelajaran menjadi satu tema. Pembelajaran Tema 6 "Cita-Citaku" terdapat muatan pembelajaran IPA dan Bahasa Indonesia. Pembelajaran Sains atau yang dikenal dengan IImu Pengetahuan Alam (IPA) berkaitan dengan cara mencari tahu suatu fenomena, fakta, dan teori, sehingga mampu menumbuhkan sikap ilmiah siswa. Selain itu melalui pembelajaran IPA dengan merumuskan masalah dan menarik suatu kesimpulan dapat membuat siswa berpikir dengan kritis (Susanto, 2016). Sedangkan mata pelajaran Bahasa Indonesia memegang peranan penting dalam upaya meningkatkan mutu pendidikan dasar khususnya Sekolah Dasar (SD) karena Bahasa Indonesia merupakan sarana berpikir untuk menumbuh kembangkan cara berpikir logis, sistematis, dan kritis.

Berpikir kritis adalah kegiatan menganalisis idea atau gagasan ke arah yang lebih spesifik, membedakannya secara tajam, memilih, mengidentifikasi, mengkaji, dan mengembangkannya ke arah yang lebih sempurna. Berpikir kritis berkaitan dengan asumsi bahwa berpikir merupakan potensi yang ada pada manusia yang perlu dikembangkan untuk kemampuan yang optimal (Susanto, 2016).

Berdasarkan hasil observasi prasiklus dan wawancara di kelas IV SD 2 Tenggeles pada tanggal 22 Oktober 2019 menunjukkan bahwa dalam pelaksanaan pembelajaran kurikulum 2013, penguasaan kompetensi dasar pengetahuan pada muatan pembelajaran Bahasa Indonesia dan IPA masih kurang. Siswa hanya membayangkan atau berpacu pada buku sebagai sumber belajar tanpa melihat secara langsung dilapangan maupun praktik, sehingga pembelajaran menjadi kurang bermakna. Guru dalam mengajar masih menggunakan metode yang berbasis Teacher Centered Learning. Dalam proses pembelajaran masih dilaksanakan secara konvensional, 
Pendas : Jurnal Ilmiah Pendidikan Dasar, ISSN Cetak : 2477-2143 ISSN Online : 2548-6950 Volume V Nomor 02, Desember 2020

yang menjadikan guru dalam memberikan penjelasan kurang optimal.

Kemampuan berpikir kritis siswa masih tergolong rendah. Hal tersebut terlihat dari 19 siswa kelas IV di SD 2 Tenggeles yang terdiri dari 12 siswa perempuan dan 7 siswa laki-laki, menunjukkan bahwa hasil yang diperoleh yaitu dari 19 siswa yang tuntas hanya sebanyak 8 orang dan tidak tuntas sebanyak 11 orang dengan nilai rata-rata klasikal 52,8 dengan kriteria tidak kritis. Berdasarkan kondisi tersebut, perlu alternatif tindakan yang mampu meningkatkan kemampuan berpikir kritis siswa dalam pembelajaran yang menarik dan menyenangkan.

Hal ini perlu dirancang pembelajaran yang membuat siswa terlibat secara aktif dalam suatu kelompok diskusi, menganalisis dan mengemukakan pendapatnya. Pembelajaran ini juga didukung dengan penggunaan media pembelajaran yang inovatif dan menarik perhatian siswa, sehingga siswa menjadi semangat dalam mengikuti proses pembelajaran. Maka dari itu diterapkan model pembelajaran Contextual Teaching and Learning berbantuan media Lempar Karet Pengetahuan.

(Shoimin, 2017) menyatakan bahwa Contextual Teaching and Learning merupakan suatu konsep belajar dimana guru menghadirkan situasi dunia nyata kedalam kelas dan mendorong siswa membuat hubungan antara pengetahuan yang dimilikinya dan penerapannya dalam kehidupan mereka sebagai anggota keluarga dan masyarakat. Sehingga dengan penerapan model ini membantu siswa untuk memahami pembelajaran dengan sangat mudah, dikarenakan model ini menekankan pemecahan masalah dengan cara menghubungkan pengetahuan yang dimiliki siswa dengan menerapkan pada kehidupannya sehari-hari. Sehingga mampu mendukung dalam meningkatkan kemampuan berpikir kritis serta siswa mampu mengembangkan potensi yang dimilikinya.

Media yang akan digunakan dalam penelitian ini adalah permainan tradisional lempar karet. Melalui permainan, siswa akan lebih semangat dan suasana belajar menjadi menyenangan. Hal itu sependapat dengan (Widodo, Puput., \& Lumintoarso, 2017) permainan 
Pendas : Jurnal IImiah Pendidikan Dasar, ISSN Cetak : 2477-2143 ISSN Online : 2548-6950 Volume V Nomor 02, Desember 2020

tradisional adalah aktivitas yang dilakukan tanpa paksaan, mendatangkan rasa kegembiraan, dalam suasana yang menyenangkan berdasarkan tradisi masing-masing daerah yang ada di lingkungan, dimainkan dengan menggunakan alat ataupun tidak menggunakan alat, dan dilakukan sesuai aturan yang sudah disepakati sebelum permainan dimulai, seperti peraturan, lapangan, jumlah pemain, dan lain sebagainya.

\section{Pelaksanaan} model pembelajaran Contextual Teaching and Learning pada penelitian ini dilaksanakan pada muatan IImu Pengetahuan Alam (IPA) dan Bahasa Indonesia. Beberapa penelitan yang sesuai dengan penelitian ini adalah (Putra, 2018) dengan penelitian yang dilakukannya, menyatakan bahwa pembelajaran berbasis CTL dan Inkuiri dapat meningkatkan kemampuan berpikir kritis siswa, dengan memahami langkah-langkah pembelajaran CTL dan inkuiri dengan baik. Sedangkan penelitian yang dilakukan oleh (Hartatik, Sri., \& Rahayu, 2018) dengan menggunakan media permainan tradisional lempar karet pemahaman peserta didik terhadap konsep perkalian di Sekolah Dasar dapat meningkat. Dengan menggunakan permainan, belajar menjadi menyenangkan dan siswa menjadi fokus dengan apa yang sedang dipelajari.

Berdasarkan uraian permasalahan di atas, dan beberapa hasil penelitian relevan, maka peneliti melakukan penelitian tindakan kelas. Rumusan masalah dalam penelitan ini adalah Penerapan model Contextual Teaching And Learning berbantuan media Lempar Karet Pengetahuan untuk meningkatkan berpikir kritis siswa pada Tema 6 Cita-Citaku kelas IV SD. Penelitian ini bertujuan untuk mendeskripsikan peningkatan Berpikir Kritis siswa pada Tema 6 Cita-Citaku kelas IV SD 2 Tenggeles dengan menerapkan model Contextual Teaching and Learning berbantuan media Lempar Karet Pengetahuan.

\section{B. Metode Penelitian}

Pelaksanaan penelitian ini yaitu di SD 2 Tenggeles Kudus dengan subyek penelitian kelas IV SD 2 Tenggeles, Kudus tahun ajaran 2019/2020 yang berjumlah 19 siswa. Penelitian tindakan kelas dilaksanakan pada bulan oktober 2019 sampai bulan Januari 2020. Penelitian ini dilakukan selama dua siklus, setiap siklusnya terdiri dari 
Pendas : Jurnal Ilmiah Pendidikan Dasar, ISSN Cetak : 2477-2143 ISSN Online : 2548-6950 Volume V Nomor 02, Desember 2020

empat tahapan yaitu perencanaan, tindakan, pengamatan dan refleksi. Teknik pengumpulan data dalam penelitian ini adalah tes dan non tes, analisis data yang digunakan dalam penelitian ini adalah analisis data kualitatif dan kuantitatif. Pelaksanaan penelitian tindakan kelas ini dilaksanakan dengan tahapan observasi awal, pembuatan proposal, bimbingan proposal, seminar proposal, pembuatan perangkat pembelajaran, pelaksanaan tindakan siklus I dan siklus II, penyusunan laporan penelitian tindakan kelas dan ujian penelitian tindakan kelas.

\section{C.Hasil Penelitian dan Pembahasan}

Berpikir kritis merupakan kegiatan menganalisis idea atau gagasan ke arah yang lebih spesifik, membedakannya secara tajam, memilih, mengidentifikasi mengkaji, dan mengembangkannya ke arah yang lebih sempurna (Susanto, 2016).

Hasil nilai kemampuan berpikir kritis siswa dalam penelitian ini diperoleh dari nilai tes evaluasi berjumlah 10 soal yang dilaksanakan pada tiap akhir siklus. Pada penelitian ini terdiri dari 2 siklus, setiap siklus terdiri dari 2 pertemuan. Hasil berpikir kritis siswa mengalami peningkatan mulai dari prasiklus, siklus I dan II. Berikut Histogram Peningkatan kemampuan berpikir kritis siswa prasiklus dan siklus I dapat dilihat pada Gambar 1.

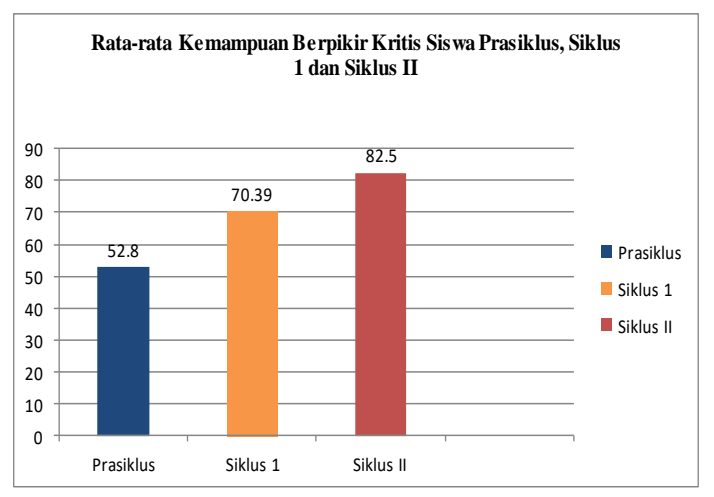

Gambar 1 Peningkatan berpikir kritis siswa prasiklus, siklus 1 dan II.

Pada Gambar 1 di atas dapat dilihat bahwa hasil kemampuan berpikir kritis prasiklus memperoleh nilai rata-rata sebesar 52,8 presentase ketuntasan belajar klasikal sebesar $42,10 \%$. Siklus I mengalami peningkatan nilai rata-rata sebesar 70,39 dengan kriteria cukup kritis, dengan presentase ketuntasan belajar klasikal sebesar $68,42 \%$. Pada siklus II terjadi peningkatan nilai rata-rata sebesar 82,5 dengan kriteria kritis, dan presentase ketuntasan belajar klasikal sebesar $84,21 \%$.

Peneliti menggunakan indikator kemampuan berpikir kritis siswa dari Ennis dalam (Susanto, 2016) yang terdiri dari lima aspek yaitu, memberikan penjelasan sederhana, 
Pendas : Jurnal IImiah Pendidikan Dasar, ISSN Cetak : 2477-2143 ISSN Online : 2548-6950

Volume V Nomor 02, Desember 2020

membangun keterampilan dasar, menyimpulkan, memberikan penjelasan lanjut, mengatur strategi dan taktik. Pada setiap indikator tersebut mengalami peningkatan dari siklus1 ke siklus II. Berikut Histogram Peningkatan indikator kemampuan berpikir kritis siswa siklus I dan siklus II dapat dilihat pada Gambar 2.

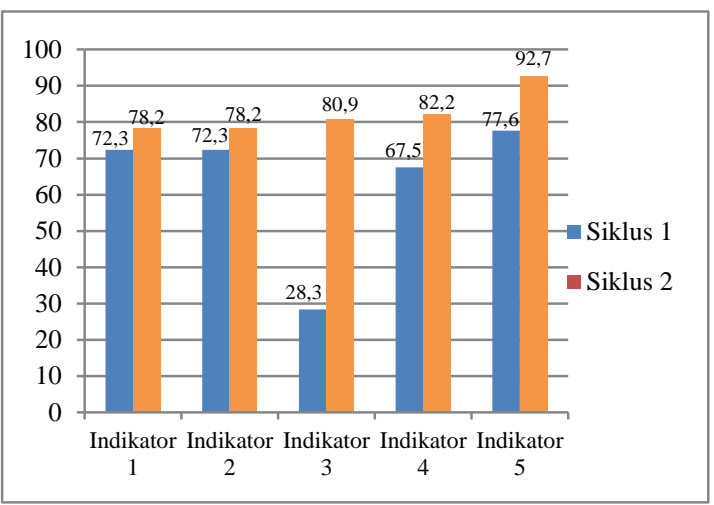

Gambar 2 Peningkatan rata-rata indikator berpikir kritis siswa siklus I dan II

Indikator 1, yaitu memberikan penjelasan sederhana, terdiri dari aspek memfokuskan pertanyaan, menganalisis argumen, hasil tes berpikir kritis siswa pada siklus 1 memperoleh rata-rata sebesar 72,3 dengan kriteria cukup kritis. Beberapa siswa sudah bisa membuat pertanyaan dari informasi yang diberikan guru tentang siklus hidup hewan, namun masih banyak siswa yang belum mengerti. Pada siklus II mengalami peningkatan dengan memperoleh jumlah rata-rata sebesar 78,2 dengan kriteria cukup kritis.

Berdasarkan hasil tes evaluasi pada siklus 1 dan siklus II kemampuan berpikir kritis siswa mengalami peningkatan. Siswa mampu menganalisis argumen dan mengambil keputusan dengan tepat. Hal tersebut sependapat dengan (Fakhriyah, Fina, Sumaji, 2016) bahwa siswa mampu membedakan antara informasi yang baik dan buruk, serta mampu mengambil keputusan dan bertanggung jawab atas informasi yang didapatkannya dengan cara berlatih membiasakan berpikir kritis.

Indikator yang kedua, yaitu memberikan keterampilan dasar. Hasil tes kemampuan berpikir kritis siswa yang terdapat pada gambar 2 yaitu pada siklus I memperoleh jumlah rata-rata 72,3 dengan kriteria cukup kritis. Beberapa siswa mampu memberikan alasan dan memilih gambar yang tepat sesuai isi puisi dan mengemukakan pendapatnya tentang permasalahan metamorfosis hewan. Siklus II terdapat peningkatan dengan memperoleh jumlah rata-rata sebesar 78,2 dengan kriteria cukup kritis.

Siklus II siswa mampu mempertimbangkan kredibilitas sumber dan mempunyai berbagai 
Pendas : Jurnal Ilmiah Pendidikan Dasar, ISSN Cetak : 2477-2143 ISSN Online : 2548-6950 Volume V Nomor 02, Desember 2020

macam jawaban untuk menyelesaikan suatu masalah yang diberikan oleh guru. Hal tersebut sependapat dengan (Rahmawati, Ika, Hidayat, Arif, Rahayu, 2016) bahwa siswa yang memiliki keterampilan berpikir kritis dapat mencermati pendapat orang lain yang benar atau salah berdasarkan kebenaran ilmiah dan pengetahuan.

Indikator yang ketiga yaitu menyimpulkan, Hasil uji tes berpikir kritis siswa siklus 1 memperoleh jumlah rata-rata sebesar 28,3 dengan kriteria tidak kritis. Masih banyak siswa yang belum mampu membandingkan siklus hidup hewan dan menyusun tahapan perkembangan dan pertumbuhan hewan. Kemudian pada siklus II mengalami peningkatan dengan memperoleh jumlah rata-rata sebesar 80,9 dengan kriteria kritis.

Siswa mampu menyusun keputusan dan mempertimbangkan hasil. Hal tersebut sependapat dengan (Fisher, 2016) bahwa untuk menilai kualitas suatu keputusan terdapat dua cara yaitu, yang pertama hanya dipandang dari segi hasil akhirnya dan yang kedua dilihat dari segi kualitas prosedur yang digunakan untuk mengambil keputusan itu.
Indikator yang keempat yaitu memberikan penjelasan lanjut, hasil tes kemampuan berpikir kritis siswa pada siklus 1 memperoleh jumlah rata-rata 67,5 dengan kriteria tidak kritis. Masih banyak siswa yang belum mampu menyikapi sebuah asumsi tentang manfaat kucing dan enentukan amanat yang terkandung dalam puisi. Dan pada siklus II meningkat dengan memperoleh jumlah rata-rata sebesar 82,2 dengan kriteria kritis.

Pada siklus II siswa mampu mengidentifikasi asumsi serta mempunyai alasan (rasional) untuk mempertanggungjawabkan apa yang telah dikemukakan. Hal tersebut sependapat dengan (Fisher, 2016) bahwa suatu argumen dapat mempengaruhi interpretasi dan evaluasinya, karena dalam suatu argumen menyediakan asumsi, dan latar belakang informasi lain.

Indikator yang kelima yaitu mengatur strategi \& taktik, Pada gambar 2 terlihat hasil tes kemampuan berpikir kritis siswa pada siklus 1 memperoleh jumlah rata-rata sebesar 77,6 dengan kriteria cukup kritis. Siswa membuat skema siklus hidup hewan dan manfaat hewan maupun tumbuhan dengan mencari 
Pendas : Jurnal IImiah Pendidikan Dasar, ISSN Cetak : 2477-2143 ISSN Online : 2548-6950 Volume V Nomor 02, Desember 2020

informasi yang berada disekitarnya maupun berinteraksi dengan teman kelompoknya. Dan pada siklus II mengalami peningkatan dengan jumlah rata-rata sebesar 92,7 dengan kriteria sangat kritis.

Siswa mampu menentukan suatu tindakan dengan menggali informasi dan bertanya pada diri sendiri serta berinteraksi dengan orang lain. Sependapat dengan (Christina, L. V., \& Kristin, 2017) bahwa berpikir kritis merupakan kemampuan seseorang dalam menemukan informasi dan pemecahan dari suatu masalah dengan cara bertanya kepada dirinya sendiri untuk menggali informasi tentang masalah yang sedang dihadapi.

Penerapan model pembelajaran Contextual Teaching and Learning berbantuan media Lempar Karet Pengetahuan membuat siswa menjadi fokus pada pembelajaran, dan suasana kelas menjadi menyenangkan. Model Contextual Teaching and Learning mengaitkan materi pelajaran dengan kehidupan nyata siswa, seperti materi siklus hidup hewan, manfaat hewan dan tumbuhan yang terdapat pada lingkungan sekitar siswa serta membuat puisi berdasarkan cita-cita masing-masing siswa. Hal tu serupa dengan pendapat (Rusman, 2012) mengemukakan bahwa inti dari model Contextual Teaching and Learning adalah keterkaitan setiap materi atau topik pembelajaran dengan kehidupan nyata.

Siswa mampu memberikan penjelasan sederhana berdasarkan argumen yang dimilikinya, dengan mengaitkan materi siklus hidup hewan dengan memperhatikan hewan yang berada di lingkungan siswa. Selain dengan penerapan model pembelajaran, kemampuan berpikir krits siswa meningkat, karena guru menggunakan permainan dalam pembelajaran yaitu permainan lempar karet. Siswa bermain lempar karet secara bergantian untuk mendapatkan kartu soal yang dikerjakan pada lembar kerja siswa dengan anggota kelompoknya. Siswa berinteraksi dengan anggota kelompoknya untuk memecahkan masalah yang terdapat pada soal. Siswa sangat antusias dalam permainan lempar karet tersebut, sehingga pembelajaran menjadi menyenangan.

Dengan memadukan model Contextual Teaching and Learning 
Pendas : Jurnal Ilmiah Pendidikan Dasar, ISSN Cetak : 2477-2143 ISSN Online : 2548-6950 Volume V Nomor 02, Desember 2020

dengan media Lempar Karet Pengetahuan ini pembelajaran menjadi lebih bermakna sehingga mampu mendukung dalam meningkatkan kemampuan berpikir kritis serta siswa mampu mengembangkan potensi yang dimilikinya.

Hasil dari penelitian ini juga didukung dari penelitian yang dilakukan oleh (Paramita., Aninditha, Japa., Ngurah, Sudatha, 2018) pada kelas kontrol model Contextual Teaching and Learning berbantuan masalah realistis berpengaruh terhadap keterampilan berpikir kritis IPA. Hasilnya lebih baik daripada kelas yang tidak dibelajarkan dengan menggunakan model Contextual Teaching and Learning Berbantuan Masalah Realistis. Penelitian oleh (Azizah, 2016) bahwa motivasi belajar siswa meningkat dengan menggunakan permainan tradisional dibandingkan pembelajaran tanpa permainan tradisional.

\section{Kesimpulan}

Peneliti menarik kesimpulan berdasarkan hasil penelitian dan pembahasan, bahwa penerapan model pembelajaran Contextual Teaching and Learning berbantuan media lempar karet pengetahuan dapat meningkatan kemampuan berpikir kritis siswa kelas IV pada tema cita-citaku muatan IPA dan Bahasa Indonesia pada peserta didik kelas IV SD 2 Tenggeles, tahun ajaran 2019/2020. Hasil kemampuan berpikir kritis pada siklus 1 sebesar 70,39\% dengan kriteria cukup dan presentase ketuntasan belajar klasikal sebesar $68,42 \%$, kemudian pada siklus II meningkat menjadi $82,5 \%$ dengan kriteria baik dan presentase ketuntasan belajar klasikal sebesar $84,21 \%$.

Simpulan yang dapat diambil dari penjabaran prasiklus, siklus 1 dan siklus II yaitu penelitian yang telah dilakukan dapat dikatakan mengalami peningkatan dan hasil peningkatan tersebut membuktikan bahwa kemampuan berpikir kritis siswa telah mencapai indikator keberhasilan yang ditentukan yaitu $\geq 70$.

\section{DAFTAR PUSTAKA}

Azizah, I. M. (2016). Efektivitas Pembelajaran Menggunakan Permainan Tradisional Terhadap Motivasi dan Hasil Belajar Materi Gaya di Kelas IV MIN Ngronggot Nganjuk. Dinamika Penelitian, 16(2), 280-308.

Christina, L. V., \& Kristin, F. (2017). 
Pendas : Jurnal Ilmiah Pendidikan Dasar, ISSN Cetak : 2477-2143 ISSN Online : 2548-6950

Volume V Nomor 02, Desember 2020

Efektivitas Model Pembelajaran Tipe Group Investigation (Gi) dan Cooperative Integrated Reading and Composition (Circ) Dalam Meningkatkan Kreativitas Berpikir Kritis Dan Hasil Belajar Ips Siswa Kelas 4. Scholaria: Jurnal Pendidikan Dan Kebudayaan, 6(3), 217-227.

Fakhriyah, Fina, Sumaji, R. M. (2016). Pengaruh Model Problem Based Instruction

Dalam

Mengembangkan Kemampuan Berpikir Kritis Siswa Sekolah Dasar. Jurnal Konseling GUSJIGANG, 2(1), 74-80.

Fisher, A. (2016). Berpikir Kritis. Jakarta: Erlangga.

Hartatik, Sri., \& Rahayu, W. D. (2018). Inovasi Model Pembelajaran Melalui Permainan Tradisional "Lempar Karet" Untuk Mengajarkan Konsep Perkalian Bagi Siswa Sekolah Dasar. Education and Human Development Journal, 3(2), 149-158.

Paramita., Aninditha, Japa., Ngurah, Sudatha, W. (2018). Pengaruh Model Contextual Teaching and Learning Berbantuan Masalah Realistis Terhadap Keterampilan Berpikir Kritis IPA siswa Kelas IV SD. TSCJ, 1(2), 56-65.

Putra, D. A. (2018). Pembelajaran Berbasis CTL dan Inkuiri untuk Meningkatkan Kemampuan Berpikir Kritis IPA Siswa Kelas V SD. Jurnal Pendidikan Dan Pembelajaran Di Sekolah Dasar, 2(3), 55-67.

Rahmawati, Ika, Hidayat, Arif, Rahayu, S. (2016). Analisis Keterampilan Berpikir Kritis Siswa
Smp Pada Materi Gaya Dan Penerapannya. Prosiding Seminar Pendidikan IPA, 1112-1119.

Rusman. (2012). Model-Model Pembelajaran. Jakarta: Raja Gravindo Persada.

Shoimin, A. (2017). 68 Model Pembelajaran Inovatif dalam Kurikulum 2013. Yogyakarta: ArRuzz Media.

Susanto, A. (2016). Teori Belajar dan Pembelajaran. Jakarta:

Prenamedia Group.

Widodo, Puput., \& Lumintoarso, R. (2017). Pengembangan Model Permainan Tradisional untuk Membangun Karakter pada Siswa Kelas Atas. Jurnal Keolahragaan, 5(2), 183-193. 